\title{
Impact of noise on hearing in the military
}

\author{
Jenica Su-ern Yong ${ }^{*}$ and De-Yun Wang
}

\begin{abstract}
Hearing plays a vital role in the performance of a soldier and is important for speech processing. Noise-induced hearing loss is a significant impairment in the military and can affect combat performance. Military personnel are constantly exposed to high levels of noise and it is not surprising that noise induced hearing loss and tinnitus remain the second most prevalent service-connected disabilities. Much of the noise experienced by military personnel exceeds that of maximum protection achievable with double hearing protection. Unfortunately, unlike civilian personnel, military personnel have little option but to remain in noisy environments in order to complete specific tasks and missions. Use of hearing protection devices and follow-up audiological tests have become the mainstay of prevention of noise-induced hearing loss. This review focuses on sources of noise within the military, pathophysiology and management of patients with noise induced hearing loss.
\end{abstract}

Keywords: Hearing loss, Noise-induced, Military personnel, Ear protective devices

\section{Introduction}

Noise-induced hearing loss is a major preventable disease. It can be caused by an acute exposure to an intense impulse of sound or by a continuous steady-state longterm exposure with sound pressure levels higher than 75-85 dB (Table 1).

Noise remains a large public health problem with an estimated 1.3 billion people being affected by hearing loss [1]. It ranks 13th globally as the cause of years lived with disability (YLD). YLD is estimated by multiplying the number of incident cases in that period with the duration of disease and the weight factor which measures disease severity. In North America, it ranks 19th as the cause of YLD, in Central Asia, it ranks 15th and in Southeast Asia it ranks 9th.

The prevalence of hearing loss and tinnitus in military population are greater than in the general public. Almost every soldier, sailor, airman or marine will be exposed to hazardous noise levels at some point in their career [2-4]. The two most prevalent service connected disabilities for veterans in the United States at the end of fiscal year 2012 remain tinnitus and hearing loss, with tinnitus affecting 115,638 veterans (9.7\%) and hearing loss affecting 69,326 veterans (5.8\%) [5]. In Finland, despite the increasing use of hearing protection devices, a large

\footnotetext{
* Correspondence: yong.suern@gmail.com

Department of Otolaryngology-Head and Neck Surgery, National University Health System, National University of Singapore, Singapore, Singapore
}

proportion of professional soldiers experience disabling tinnitus and hearing loss [6].

Hearing acuity is a key component of a soldier's effectiveness in the battlefield. The presence of tinnitus and hearing loss can significantly impair a soldier's ability to hear important acoustic cues or communication signals from the unit or the enemy [2]. Hearing problems can also be a reason for disruption of their military service. In a study by Muhr et al., 33 soldiers (3.9\%) had interrupted training as a result of their hearing problems [7].

\section{Review \\ Sources of noise-induced hearing loss Land force}

Sources of noise within the military vary with soldier's designation. Within the Belgian military, Fighting in Built-Up Area (FIBUA) training, shooting with large calibre weapons and participation in military exercises were the strongest determinants of hearing loss [4].

Within the infantry, weapons emit high levels of noise. Table 2 depicts the amount of permissible noise allowed and Table 3 depicts the typical noise level emitted by different weapons. Many weapons emit sounds that exceed the maximum achievable protection that double hearing protection can offer. Double hearing protection means both earmuffs and ear plugs are used. The US Department of Defense published a medical surveillance monthly report on noise-induced hearing loss and it was found that 
Table 1 Glossary of terms used

\begin{tabular}{|c|c|}
\hline Terms & Descrption \\
\hline $\begin{array}{l}\text { Sound pressure } \\
\text { level (SPL) }\end{array}$ & $\begin{array}{l}\text { Sound intensity is expresses the pressure caused by a } \\
\text { sound wave and is indicated by sound pressure level. } \\
\text { The unit of measurement is the decibel (dB SPL) }\end{array}$ \\
\hline dB Scale & A logarithmic scale to measure sound pressure level \\
\hline dBA & $\begin{array}{l}\text { To measure noise, A-weighted SPL (dBA) can be used. } \\
\text { In contrast to SPL which represents a physical } \\
\text { dimension, A-weighted SPL represents a perceptual } \\
\text { dimension. The dB SPL will be different from dBA } \\
\text { for different for different frequencies as low } \\
\text { frequency sounds and high frequency sounds } \\
\text { tend to be less loud than mid-frequency sounds }\end{array}$ \\
\hline $\mathrm{L}_{\text {Aeq }}$ & $\begin{array}{l}\text { This refers to the average level of sound pressure } \\
\text { within a certain time period with the A-filter used } \\
\text { for frequency weighting. The A-filter is a } \\
\text { frequency-weighting of sound pressure levels that } \\
\text { mimics the sensitivity of the auditory system of } \\
\text { humans (eg, low-frequency sounds contribute } \\
\text { little to the A-weighted dB level) }\end{array}$ \\
\hline
\end{tabular}

noise-induced hearing injuries were more prevalent among combat-specific occupations (41.2 per 1000 person-years of active component military service) [8].

\section{Navy}

In the Navy, the highest indoor noise levels were found in engine rooms $[9,10]$. Landing ship tanks and patrol vessels typically generated about 98 to $103 \mathrm{dBA}$ of noise, whereas the noise level in missile gun boats were at 120 $\mathrm{dBA}$ [9]. The loudest noise generated is on the carrier decks that can range from 130 to $160 \mathrm{dBA}$ [2].

\section{Air force}

Military aircraft personnel are not spared, the average noise experienced in service helicopters was found to be $97 \mathrm{dBA}$ for 'Gazelle', $99.8 \mathrm{dBA}$ for the 'Scout', $99.9 \mathrm{dBA}$ for the 'Puma' and $100 \mathrm{dBA}$ for the 'Lynx' [11]. In fighter planes, the noise level ranged from 97 to $104 \mathrm{dBA}$, in jet

Table 2 Amount of permissible noise exposure allowed in theworkplace*

\begin{tabular}{ll}
\hline Duration per day (hour) & Sound level (dBA) \\
\hline 8 & 90 \\
6 & 92 \\
4 & 95 \\
3 & 97 \\
2 & 100 \\
$1 / 2$ & 102 \\
1 & 105 \\
$1 / 2$ & 110 \\
$1 / 4$ or less & 115 \\
\hline
\end{tabular}

*Adapted from OSHA 2014. Standards. US Dept Labor: Occupational Noise Exposure [Online]. vailable by Occupational Safety and Health Administration. https://www. osha.gov/SLTC/noisehearingconservation/index.html. trainers the noise level was at 100 to $106 \mathrm{dBA}$ and in transporter aircrafts, the noise level was found to be between 88 to $101 \mathrm{dBA}$ [12]. In such settings, due to chronic noise exposure, pilots were found to exhibit hearing impairment [13].

\section{Pathophysiology}

Injury from noise can occur in 2 main ways. First, high level, short duration exposure exceeding more than $140 \mathrm{~dB}$ can cause the delicate inner ear tissues to beyond stretch beyond their elastic limits. This causes mechanical disruption of the sterocilia and direct damage to supporting and sensory cells [14]. In such cases, the maximum sound pressure level (SPL) is more important than the duration of the exposure [15]. This type of acoustic trauma can result in immediate and permanent hearing loss.

Second, long term exposure to low level noise damages the cochlea metabolically rather than mechanically. It involves biochemical pathways leading to cell death either through apoptosis or necrosis [16]. There are 2 factors that influence which cell death pathway is activated. The first factor is the sound intensity level. Noises of $105 \mathrm{~dB}$ favour necrosis whereas louder noises $(120 \mathrm{~dB})$ favour apoptosis [17]. Another factor is the time between noise exposure and morphological analysis. Outer hair cells immediately start dying during the initial acoustic insult and continue to do so for at least 30 days after the event $[18,19]$. Immediately after the insult, apoptosis is the main cause of cell death. After 4 days, the apoptotic activities start to diminish and by day 30 both apoptosis and cell necrosis contribute equally to cell death $[19,20]$.

Exposure to intense sound can cause auditory thresholds to become elevated permanently or temporarily. Reversible hearing loss is referred to as temporary threshold shift (TTS). Depending on duration of exposure, recovery from TTS can occur over a period of minutes to hours or days. If TTS does not recover, permanent hearing loss results and this is referred to permanent threshold shift (PTS) [21]. These two phenomena, permanent and temporary threshold shifts are still not well understood.

PTSs are postulated to be either due to direct mechanical trauma or metabolic overstimulation of cellular elements within the organ of Corti which is associated with generation of reactive oxygen species [22].

Various mechanisms have been proposed for TTS and include synaptic fatigue, metabolic fatigue of either stria vascularis or hair cells and changes in cochlear blood flow. An important component of noise-induced hearing loss is postsynaptic damage in the afferent dendrites beneath the inner hair cells [23]. Even though hair cells recover normal function, there is rapid extensive and 
Table 3 Peak sound pressure level range of different weapons*

\begin{tabular}{ll}
\hline Type of weapons & $\begin{array}{l}\text { Peak sound pressure level } \\
\text { range }(\mathbf{d B})\end{array}$ \\
\hline Rifles & $155.2-159.9$ \\
$.45-70$ Rifle & $158.7-163.1$ \\
$.30-06$ Rifle & \\
Shotguns & $151.0-157.3$ \\
.410 Bore & 154.8 \\
20 Gauge & $156.1-161.5$ \\
12 Gauge & \\
Pistols & 151 \\
.22 & 159163 \\
9 mm Luger & 158 \\
.45 ACP & 158 \\
Other Weapons & 184 \\
Hand grenade & $L_{\text {Aeq }}^{103-107}$ \\
\hline Light anti-tank weapon & \\
Inside armored vehicle, continuous noise
\end{tabular}

*Adapted from Chen L, Brueck SE. Noise and lead exposure at an outdoor firing range - California. Health Hazard Evaluation report Sept 2011, and from Kramer WL. Gunfire noise and hearing. American Tinnitus Association. June 2002:14-15.

irreversible loss of synapses and delayed and progressive loss of cochlear neurons over many months $[24,25]$. This resultant cochlear neuropathy has been observed in mice exposed to just 84 dB SPL over a week [26]. It is possible that many people with difficulty in hearing also suffer from noise-induced cochlear neuropathy seen in animal studies.

Noise not only increases hearing threshold, but it can also cause tinnitus and hyperacusis. This can be present in individuals with normal hearing thresholds but with cochlear neuropathy. Indeed, studies have shown that patients with tinnitus have evidence of reduced Wave I at high sound levels [25,27]. The pathogenesis of tinnitus is postulated to be due to a compensatory increase in neural gain to the auditory brainstem as a result of reduced neural output from cochlea $[27,28]$. The gain can lead to tinnitus due to the amplification of spontaneous activity of auditory neurons.

\section{Clinical presentation Symptoms and signs}

Exposure to noise can induce several hearing symptoms such as temporary threshold shifts (TTS), tinnitus, hyperacusis, recruitment, distortion or abnormal pitch perception [29]. Tinnitus can occur in the presence or absence of an abnormal audiogram. The tinnitus pitch match is associated with the frequency spectrum of hearing loss [30,31].
Patients may exhibit difficulty in listening to high frequency noise such as whistles or buzzers. They may also have difficulty differentiating some speech consonants, especially if they are in areas where there is significant background noise.

However these symptoms are typically insidious and most patients with noise induced hearing loss may not notice their deficiency until it starts to affect communication.

\section{Audiometric characteristics}

Noise-induced deafness usually occurs at high frequencies with hearing loss beginning around $4 \mathrm{kHz}$ or $6 \mathrm{kHz}$. However, as the disease progresses, hearing loss will also be seen at the lower frequencies. The expected maximal changes in thresholds are predictable at one-half octave above maximal frequency of the exposure [32].

The audiometric pattern in noise induced hearing loss is usually symmetrical and bilateral. However some asymmetry is not unexpected. The asymmetry in hearing threshold may be partly explained by the position of head during work [33]. Hong et al. studied workers in the American construction industry and it was found that the left ear predominantly experienced more hearing loss than the right. Asymmetry was postulated to be due to the work habit that the operators look over their right shoulder when operating heavy equipment, exposing their left ear to the noise generated by the machines [34]. Hearing loss among rifle shooters also tend to be asymmetrical, as hearing in the ear closest to the barrel tends to be worse as it is closer to the explosion whereas the other ear is protected by the head $[12,35]$. In the civilian population, this was also seen in musicians who played high string instruments where the left ear was found to be exposed to $4.6 \mathrm{~dB}$ more than the right ear [36].

\section{Management of patients Noise prevention}

Within the military setting, noise exposure may be controlled through isolation (distance and physical barriers), vibration dampening, insulation and proper equipment maintenance [37]. The preferred method of preventing noise induced hearing loss and noise induced tinnitus is engineering controls. Other methods including the use of hearing protection devices such as foam ear plugs, molded insets and sound attenuating ear muffs are limited and can diminish perception of speech. Prevention is also reliant on the individual's compliance to the sound protection devices.

Currently, the Navy considers $85 \mathrm{dBA}$ to be the threshold for single hearing protection and 104 dBA for double hearing protection for steady state noise settings [38]. Noise levels on the flight deck during flight and some aircraft maintenance operations are intense and can 
easily exceed the $104 \mathrm{dBA}$ threshold for double hearing protection [2].

In the British Army Air Corps, pilots of the Lynx have to wear the Mk4 flying helmet and pilots of the Apache wear the Integrated Helmet and Display Sighting System (IHADSS). Circumaural earmuffs are integrated into the aircrew helmet system. Lang et al. found that hearing was better than predicted in nearly all frequencies for both ears for both Lynx and Apache pilots, demonstrating that the circumaural earmuffs implemented reduce the risk of noise induced hearing loss [39].

Even the best hearing protection equipment will be ineffective if it is not used properly or if soldiers are not compliant. A focus group study found that main concerns with hearing protection were interference with detection and localization of auditory warning and perception of orders [40]. Bjorn et al. conducted a study on the hearing protection equipment use by the crew on the flight deck and found that $79 \%$ of flight deck personnel received an estimated $0-6 \mathrm{~dB}$ rather than the expected 28-30 dB of noise attenuation from either misuse of earplugs or non-compliance to ear plugs [41].

\section{Pharmacotherapy}

Currently there is no established treatment for patients and it is limited to prevention and follow-up. However recent clinical trials have proved promising.

\section{Magnesium}

Magnesium efficacy was tested in a double-blind study. Test subjects were given either $122 \mathrm{mg}$ of magnesium or a placebo for 10 days and thereafter subjected monoaurally to $90 \mathrm{~dB}$ SPL of white noise for 10 minutes. TTS of $>20 \mathrm{~dB}$ was found in $28 \%$ of the placebo group compared to $12 \%$ in the magnesiumsupplemented group [42].

Attias et al. conducted a double-blind placebo controlled study on army recruits and concluded that recruits who had magnesium supplementation had less frequent noise-induced PTS compared to the placebo group [43]. These 300 army recruits underwent basic military training where they were subjected to shooting range noises of an average peak level of $164 \mathrm{dBA}$ and $<1 \mathrm{~ms}$ duration with the use of ear plugs which reduced noise level by about $25 \mathrm{dBA}$. PTS was defined as a threshold $>25 \mathrm{~dB}$ hearing loss in at least 1 frequency and it was found that PTS was higher in placebo group (11.5\%) as opposed to the participants in the magnesium group (1.2\%).

\section{$\mathrm{N}$-acetyl-cysteine (NAC)}

NAC acts as a reactive oxygen species scavenger and is postulated to reduce noise-induced hearing loss by reducing the exposure of the cochlea to reactive oxygen species. Glutathione S-transferases (GST) are a family of detoxification enzymes which help cells resist oxidative injury. Glutathione detoxification can be affected in individuals with genetic polymorphisms involving deletion of base pairs in the genes like GSTT1 and GSTM1. Patients with these two high-risk genotypes are more prone to have oxidative injury from noise induced hearing loss $[44,45]$. In a trial conducted on steel manufacturing workers, employees were administered either $1200 \mathrm{mg}$ of NAC or placebo. Trial was conducted in a $2 \times 2$ crossover design with subjects taking either NAC or placebo for 14 days and with a 14-day wash-out period between treatments. Noise exposure was $88.4-89.4 \mathrm{~dB}$ as assessed by personal noise monitoring. The difference between the TTS was not found to be significant. However, when the subjects were subdivided based on genetic polymorphisms or GSTT1 and GSTM1, the subgroup with null genotypes in both GSTT1 and GSTM1 experienced protection by NAC [46].

\section{Methionine (MET)}

Another glutathione (GSH) precursor is MET, an essential amino acid that can be converted to cysteine, which is the rate-limiting substrate for GSH production. It has been shown in animal studies to be otoprotective when administered at $200 \mathrm{mg} / \mathrm{kg}$ [47]. A major limitation in human studies are high-doses administration, route of administration and bioavailability.

\section{Ebselen}

Ebselen is a potent glutathione peroxidase mimic and neuroprotectant. It also has strong activity against peroxynitrite, a super reactive oxygen species $[48,49]$. It reduces cytochrome $\mathrm{c}$ release from mitochondria and nuclear damage during lipid peroxidation [50]. Since it acts as a catalyst, low does maybe sufficient to prevent or treat noise induced hearing loss [51]. Phase II trials are currently in progress to determine the efficacy of oral ebselen.

\section{Conclusion}

Noise-induced hearing loss is a serious disease burden in the military. Due to the nature of the military profession, hearing is a vital asset during tactical and survival training and exposure to loud noises during training and missions are inevitable. Prevention is still the mainstay of treatment and soldiers need to be educated with regards to the use of hearing protection devices.

\section{Competing interests}

The authors declare that they have no competing interests.

\section{Authors' contributions}

JSY made significant contributions in preparing and writing the manuscript. DYW was substantially involved in writing and revising the manuscript for publication. Both authors have read and approved the final manuscipt. In 
addition, both authors agree to be accountable for all aspects of the work. Both authors read and approved the final manuscript.

\section{Received: 16 August 2014 Accepted: 30 January 2015 Published online: 25 February 2015}

\section{References}

1. US Burden of Disease Collaborators. The state of US health, 1990-2010: burden of diseases, injuries, and risk factors. JAMA. 2013;310:591-608.

2. Yankaskas K. Prelude: noise-induced tinnitus and hearing loss in the military. Hear Res. 2013;295:3-8.

3. Pfannenstiel TJ. Noise-induced hearing loss: a military perspective. Curr Opin Otolaryngol Head Neck Surg. 2014;22:384-7.

4. Collee A, Legrand C, Govaerts B, Van Der Veken P, De Boodt F, Degrave E. Occupational exposure to noise and the prevalence of hearing loss in a Belgian military population: a cross-sectional study. Noise Health. 2011;13:64-70.

5. Annual Benefits Report, Fiscal Year 2012. Department of Veteran Affairs. 2012. http://www.va.gov/budget/report. Accessed 15 Feb 2013.

6. Ylikoski ME, Ylikoski JS. Hearing loss and handicap of professional soldiers exposed to gunfire. Scand J Work Environ Health. 1994;20:93-100.

7. Muhr $P$, Rosenhall $U$. The influence of military service on auditory health and the efficacy of a Hearing Conservation Program. Noise Health. 2011;13:320-7.

8. Helfer TM. Noise-induced hearing injuries, active component, U.S. Armed Forces, 2007-2010. MSMR. 2011;18:7-10

9. Ong M, Choo JT, Low E. A self-controlled trial to evaluate the use of active hearing defenders in the engine rooms of operational naval vessels. Singapore Med J. 2004;45:75-8.

10. Sunde E, Irgens-Hansen K, Moen BE, Gjestland T, Koefoed VF, Oftedal G, et al. Noise and exposure of personnel aboard vessels in the Royal Norwegian Navy. Ann Occup Hyg. 2014;16:1-18.

11. Owen JP. Noise induced hearing loss in military helicopter aircrew - a review of the evidence. J R Army Med Corps. 1995;141:98-101.

12. Kuronen P, Toppila E, Starck J, Paakkonen R, Sorri MJ. Modelling the risk of noise-induced hearing loss among military pilots. Int J Audiol. 2004:43:79-84.

13. Paakkoenen $R$, Kuronen $P$. Noise exposure of fighter pilots and ground technicians during flight rounds. Acustica Acta Acustica. 1997;83:1-6.

14. Slepecky N. Overview of mechanical damage to the inner ear: noise as a tool to probe cochlear function. Hear Res. 1986;22:307-21.

15. Clark WW, Bohne BA. Effects of noise on hearing. JAMA. 1999;281:1658-9.

16. Op de Beeck K, Schacht J, Van Camp G. Apoptosis in acquired and genetic hearing impairment: the programmed death of the hair cell. Hear Res. 2011;281:18-27.

17. Hu BH, Guo W, Wang PY, Henderson D, Jiang SC. Intense noise-induced apoptosis in hair cells of guinea pig cochleae. Acta Otolaryngol. 2000;120:19-24.

18. Hamernik RP, Turrentine G, Roberto M, Salvi R, Henderson D. Anatomical correlates of impulse noise-induced mechanical damage in the cochlea. Hear Res. 1984;13:229-47

19. Yang WP, Henderson D, Hu BH, Nicotera TM. Quantitative analysis of apoptotic and necrotic outer hair cells after exposure to different levels of continuous noise. Hear Res. 2004;196:69-76.

20. Hu BH, Henderson D, Nicotera TM. Involvement of apoptosis in progression of cochlear lesion following exposure to intense noise. Hear Res. 2002;166:62-71.

21. Lonsbury-Martin BL, Martin GK: Noise-Induced Hearing Loss. In Cummings, Flint PW, Haughey BH, Lund VJ, Niparko JK, Richardson MA, Robbins KT, Thomas JR, editors. Philadelphia, Mosby Elsevier. 2010. 2140-2152.

22. Henderson D, McFadden SL, Liu CC, Hight N, Zheng XY. The role of antioxidants in protection from impulse noise. Ann N Y Acad Sci. 1999;884:368-80.

23. Pujol R, Puel JL. Excitotoxicity, synaptic repair, and functional recovery in the mammalian cochlea: a review of recent findings. Ann N Y Acad Sci. 1999:884:249-54

24. Heeringa AN, van Dijk P. The dissimilar time course of temporary threshold shifts and reduction of inhibition in the inferior colliculus following intense sound exposure. Hear Res. 2014;312:38-47.
25. Kujawa SG, Liberman MC. Adding insult to injury: cochlear nerve degeneration after "temporary" noise-induced hearing loss. J Neurosci. 2009;29:14077-85.

26. Maison SF, Usubuchi H, Liberman MC. Efferent feedback minimizes cochlear neuropathy from moderate noise exposure. J Neurosci. 2013;33:5542-52.

27. Schaette R, McAlpine D. Tinnitus with a normal audiogram: Physiological evidence for hidden hearing loss and computational model. J Neurosci. 2011;31:13452-7.

28. Schaette R, Kempter R. Development of tinnitus related neuronal hyperactivity through homeostatic plasticity after hearing loss: A computational model. Eur J Neurosci. 2006;23:3124-38.

29. Zhao F, Manchaiah VK, French D, Price SM. Music exposure and hearing disorders: an overview. Int J Audiol. 2010;49(1):54-64.

30. Norena A, Micheyl C, Chery-Croze S, Collet L. Psychoacoustic characterization of the tinnitus spectrum: implications for the underlying mechanisms of tinnitus. Audiol Neurootol. 2002;7:358-69.

31. Schecklmann M, Vielsmeier V, Steffens T, Landgrebe M, Langguth $B$, Kleinjung T. Relationship between audiometric slope and tinnitus pitch in tinnitus patients: insights into the mechanisms of tinnitus generation. PLoS One. 2012;7:e34878.

32. Melnick W. Temporary and permanent threshold shift. In: Lipsomb M, editor. Noise and Audiology. Baltimore: University Park Press; 1978. p. 83-107.

33. World Health Organization (WHO). Hearing impairment caused by noise. early detection of occupational disease. Geneva, Switzerland: World Health Organization; 1986. p. 165-9.

34. Hong $\mathrm{O}$. Hearing loss among operating engineers in American construction industry. Int Arch Occup Environ Health. 2005;78:565-74.

35. Sataloff RT, Sataloff J. Occupational Hearing Loss. 3rd ed. Boca Raton, FL: CRC Press; 2006.

36. Jansen EJ, Helleman HW, Dreschler WA, de Laat JA. Noise induced hearing loss and other hearing complaints among musicians of symphony orchestras. Int Arch Occup Environ Health. 2009;82:153-64.

37. Humes LE, Joellenbeck LM, Durch JS. Noise and military service: implications for hearing loss and tinnitus. Washington, DC: Institute of Medicine of the National Academies; 2005.

38. US-Navy. Navy Safety and Occupational Health (SOH) Program Manual. Washington DC: Department of the Navy; 2010.

39. Lang GT, Harrigan MJ. Changes in hearing thresholds as measured by decibels of hearing loss in British Army Air Corps lynx and apache pilots. Mil Med. 2012;177:1431-7.

40. Abel SM. Barriers to hearing conservation programs in combat arms occupations. Aviat Space Environ Med. 2008;79:591-8.

41. Bjorn VS, Albert CB, McKinley RL: US Navy flight deck hearing protection use trends: survey results. In: New directions for improving audio effectivness. Neuilly-sur-Seine, France: Research Technology Organization. 2005. http://www.dtic.mil/dtic/tr/fulltext/u2/a455113.pdf. Accessed.1 April 2015.

42. Attias J, Sapir S, Bresloff I, Reshef-Haran I, Ising H. Reduction in noise-induced temporary threshold shift in humans following oral magnesium intake. Clin Otolaryngol Allied Sci. 2004;29:635-441.

43. Attias J, Weisz G, Almog S, Shahar A, Wiener M, Joachims Z, et al. Oral magnesium intake reduces permanent hearing loss induced by noise exposure. Am J Otolaryngol. 1994;15:26-32.

44. Bruhn C, Brockmöller J, Kerb R, Roots I, Borchert HH. Concordance between enzyme activity and genotype of glutathione S-transferase theta (GSST1). Biochem Pharmacol. 1998;56:1189-93.

45. Wiencke JK, Wrensch MR, Miike R, Zuo Z, Kelsey KT. Population-based study of glutathione S-transferase mu gene deletion in adult glioma cases and controls. Carcinogenesis. 1997;18:1431-3.

46. Lin CY, Wu JL, Shih TS, Tsai PJ, Sun YM, Ma MC, et al. N-Acetyl-cysteine against noise-induced temporary threshold shift in male workers. Hear Res. 2010;269:42-7.

47. Kopke RD, Weisskopf PA, Boone JL, Jackson RL, Wester DC, Hoffer ME, et al. Reduction of noise induced hearing loss using L-NAC and salicylate in the chinchilla. Hear Res. 2000;149:138-46.

48. Noguchi N, Yoshida Y, Kaneda H, Yamamoto Y, Niki E. Action of ebselen as an antioxidant against lipid peroxidation. Biochem Pharmacol. 1992:44:39-44

49. Noguchi N, Gotoh N, Niki E. Effects of ebselen and probucol on oxidative modifications of lipid and protein of low density lipoprotein induced by free radicals. Biochim Biophys Acta. 1994;1213:176-82. 
50. Kowaltowski AJ, Netto LE, Vercesi AE. The thiol-specific antioxidant enzyme prevents mitochondrial permeability transition. Evidence for the participation of reactive oxygen species in this mechanism. J Biol Chem. 1988:273:12766-9.

51. Muller A, Gabriel H, Sies H, Terlinden R, Fischer H, Romer A. A novel biologically active selenooorganic compound-VII. Biotransformation of ebselen in perfused rat liver. Biochem Pharmacol. 1988;37:1103-9.

Submit your next manuscript to BioMed Central and take full advantage of:

- Convenient online submission

- Thorough peer review

- No space constraints or color figure charges

- Immediate publication on acceptance

- Inclusion in PubMed, CAS, Scopus and Google Scholar

- Research which is freely available for redistribution 